\title{
The Application of Clinical Learning Online in the Pandemic Time Covid-19 at the Faculty of Medicine Mulawarman of University
}

\author{
Anik Puji Rahayu ${ }^{1}$, Sulistiawati $^{2}$, Cicih Bhakti Purnamasari $^{3}$, Endang Sawitri ${ }^{4}$, Ika Fikriah $^{5}$ \\ 1,2,3,4,5 Faculty of Medicine, Mulawarman of University
}

Author correspondency: anikpuji@fk.unmul.ac.id

\begin{abstract}
The government's policy of implementing social distancing, work from home, and study from home to prevent the spread of the Covid-19 coronavirus has an impact on learning methods (Abel \& McQueen, 2020). Clinical learning methods in health education before the pandemic are carried out in campus laboratories and clinical services directly to patients. So, with this condition, it cannot be carried out in accordance with the provisions. It is necessary to modify the learning method from offline to online to meet the continuity of the student learning process. The clinical learning method for procedural skills is carried out by using online videos, supported by lecturers' explanations with a 120minute meeting, then in the second stage students are given the task of making a video of procedural skills that have been taught within 170- minutes, the duration of the video is 10-15 minutes. At the next meeting, a review or response was conducted to the SOP and the theory that underlies it. The design in this research is descriptive correlation analysis with the number of respondents 511 students of the medical education study program and nursing diploma 3 study program. The number of questionnaires used was 44 statement items, sent and filled out via Google Forms. The results of this study have a significant relationship between the perceptions of students who apply online clinical learning as seen from the aspects of knowledge, skills, and attitudes with the effectiveness of learning in the Covid-19 pandemic era with a p-value $=0.000$, with a very strong relationship with the Spearman value. rho 0.791 with a positive direction, thus it can be concluded that the application of online clinical learning during the Covid-19 pandemic was effective. Suggestions, to modify clinical learning methods with various blended learning or hybrid learning methods.
\end{abstract}

Keywords: Application, clinical learning, Covid-19 pandemic.

\section{INTRODUCTION}

Social distancing is a policy to prevent the spread of coronavirus of 19 , because as much as possible, stay at home, stay away from the crowd, and not travel if it is not necessary. Social distancing, which means keeping a distance from social life or keeping a physical distancing from other people, will slow down the spread of the coronavirus a which occurs through droplet contamination or saliva splashes at a distance of 1 or 2 meters with social distancing, so the risk of contracting Covid- 19 from others will decrease[1].
The Coronavirus that continues to spread in Indonesia has made various elements decide to follow government directions by working from home or working at home. The Coronavirus is because social distancing is one of the most appropriate steps to reduce the spread of infection. Several steps to continue the teaching and learning process were carried out using an online system. Based on the Circular of the Minister of Education and Culture of the Republic of Indonesia No. 3 of 2020 concerning the Prevention of COVID-19 in the Education unit, all higher education in Indonesia has taken firm steps on the government's appeal to carry out learning activities from home[2]. 
In general, clinical learning methods in health education, before the pandemic period, were carried out by learning in campus laboratories with live demonstrations by lecturers, coupled with clinical skills video screening, and students doing these skills to be assessed by the lecturer. After a pandemic, the student can go down to the clinical practice to hold the patient and carry out his clinical skills competence by directly with the guidance and assessment of the clinical supervisor. Higher education institutions make many Internet-based applications for familiar with the term elearning (both in the form of a website and application) [3].

E-learning is an electronic system-based learning process, where the benefits are increasing the ability to learn independently and the ability to display information with technological devices. The weakness implementation of online clinical learning is the online procedural skills learning process system, one of which is that not all lecturers and students have the same level of understanding on operating devices and internet network problems (such as the quota runs out and the internet network often errors when in the regions)[4].

Meanwhile, the negative side of the online procedural skills learning implementation system is that not all students have the same level of understanding. For students who are diligent and easy to absorb information conveyed in the online tutoring process, it will be easily absorbed, but for those who are not familiar with this method, they will likely that they will have difficulty not only absorbing time during the online-based learning process conveyed by the lecturer but also the ability to adapt to technology applications used in online guidance process activities[5].

The learning process of clinical procedures in health education is the most crucial thing and must receive attention and solutions to overcome it during this pandemic to keep it running effectively and sustainably. One of them is to continue learning clinical procedures online. The online method used is the lecture method and video playback on clinical skills, and then by giving assignments to students to make videos about the procedural skills that have been responses, at the next meeting that will be a review or responsiveness by the lecturer by following the assessment SOP and theory concepts related to these clinical skills.

\section{RESEARCH PROBLEM AND RESEARCH OBJECTIVE}

The effective and efficient application of clinical learning is one way to guarantee the quality of the health education management system in general. The key to the success of students whose assessment must reach $100 \%$ is in learning clinical skills.
Based on the above background, the researchers wanted to analyze the clinical learning process carried out online at the Faculty of Medicine at Mulawarman University, including:

1. How is the application of clinical learning phase-1 explaining clink procedure skills with videos and online dossiers during the Covid-19 pandemic?

2. How is the application of stage 2 clinical learning, namely giving assignments to students to make video skills procedures that have been taught, then reviewing or responding with SOP assessments and clinical procedural skills theory online during the Covid-19 pandemic ?

3 . How is the application of clinical learning in stages 1 and 2, namely learning clinical procedural skills using videos and lectures from lecturers, giving assignments to make videos and conducting reviews or responses according to the SOP and the theory of clinical procedure skills online during the Covid-19 pandemic?

\section{RESEARCH METHODOLOGY}

This type of research is quantitative research, with a de scriptive analytic approach. The design in this study is cross sectional, where the dependent and independent variable data are obtained in one time period. The sample was 511 respondents using random sampling technique from all students in the medical faculty of Mulawarman University. Analysis of the bivariate data using the Spearman rho trial[6].

\section{RESULT AND DISCUSSION}

Students who become respondents are students who have experienced this clinical learning method. The univariate variables that will be seen are the online learning methods at stage 1 , stage 2 and the second stage covering the aspects of knowledge, skills and attitude of the online learning process, and also how the effectiveness of learning at stage 1, stage 2 and both stages from the point of view. college student.

Based on the research data, the majority of students came from medical education study programs as many as 308 people $(60.3 \%)$, and $39.1 \%$ from diploma 3 nursing study programs. This makes it easier to obtain valid data because this learning method has been implemented in the medical education study program since the first semester. Students who filled up the most appropriate questionnaires were students in semester 3 and above, namely 352 people $(68.9 \%)$, which allowed the results to be more valid and effective. This is in accordance with the sample criteria, namely students who have participated in learning methods like this.

The results of this study indicate that online clinical learning in stage- 1 is providing explanations using videos and explanations from the lecturers, as many as 262 students stated that they were good (51.7\%), and 293 students stated that this learning was effective $(57,3 \%)$. 
The results of this study indicate that online clinical learning in stage- 2 is to provide a task to make a skill video according to what has been taught and then the Lecturer will respond according to the SOP and the theoretical concept of these skills, and as many as 312 students stated that this stage of learning was good 61\%), and students who stated that this learning was effective were 268 people $(52.4 \%)$.

The results of this study indicate that online clinical learning in stages- 1 to 2 , namely providing explanations using videos and explanations from the lecturer, then given the task of making video skills according to what has been taught and then responding will be carried out by the lecturer according to the SOP and theoretical concepts from these skills, and as many as 295 students said it was good $(57.7 \%)$, and students who stated that this learning was effective were 281 people (54.9\%).

Related by research on the application of learning methods in the new clinic has also been carried out concerning the Effectiveness of Clinical Learning Methods on Critical Thinking Ability and SelfConfidence : A Literature Review. The based results search of the literature found that learning methods can improve the critical thinking skills and self-confidence of nursing students with the method simulation, and make videos of clinical procedural skills to direct the patient[7].

Reflections on clinical skills laboratory learning stated that learning clinical skills in the world is increasing rapidly along with the development of medical science and education and technology. Clinical skill learning. The covers three competencies, namely knowledge, skills, and attitude a doctor must-have. Clinical skills practice can be getting with patients and at the clinical skills centers. Many factors influence the clinical skills learning process. In learning clinical skills, there are many aspects that instructors must know. Prepare the curriculum, manuals, procedural, content, instructors, student motivation, and the environment[8].

Clinical Skill Lab (CSL) is a means for students to learn basic clinical skills whose training will be harmless and safe for patients. The addition of video teaching media in clinical skills learning is one way to improve students' clinical skills. This study aims to see the additional effect of video teaching media on the clinical skills of neuromotor physical examination of students of the FKIK UNJA Medical Study Program, involving 128 students[9]. Students in the group Who did not take part in the clinical skills learning session in the laboratory with the instructor of student can continue to practice clinical skills based on the step-by-step guide as shown in the teaching video. Thus, teaching videos can be a learning medium that needs to be considered to be developed into learning resources to overcome the limited time and resources of lecturers that may be encountered in medical faculties (Comparison of the Effectiveness of Clinical Skill Lab (CSL) Learning Using
Neurology Clinical Skills Teaching Videos on Demonstrations[10].

\section{CONCLUSIONS}

Based on the research data, the highest number of students came from the medical education study program as many as 308 people $(60.3 \%)$, and the 3rd semester students and above were 352 people $(68.9 \%)$. The results of this study indicate that online clinical skills learning at stage- 1 is to provide explanations for teaching clinical skills using videos and also explanations from lecturers, as many as 262 students stated that the clinical skills learning method was good $(51.7 \%)$, and students who 293 people $(57.3 \%)$ stated that this learning was effective.

The results of this study indicate that online clinical learning in stage- 2 is to provide a task to make a video of the skills that have been taught and then a review or response will be carried out by the lecturer according to the SOP and theoretical concepts of these skills, and as many as 312 students stated learning This stage is good $(61 \%)$, and students who stated this learning was effective were 268 people $(52.4 \%)$.

The results of this study indicate that online clinical learning in stages- 1 to 2 is providing explanations using videos and explanations from the lecturer, then given the task of making video skills according to what has been taught and then responsiveness will be carried out by the lecturer according to SOP and concepts the theory of these skills, and as many as 295 students said it was good $(57.7 \%)$, and students who stated that this learning was effective were 281 people $(54.9 \%)$.

Based on the results of the study, there is a relationship between learning clinical procedural skills online during the Covid-19 pandemic using videos and lecturers' explanations with a very strong learning effectiveness and positive direction. Based on the research results that there is a relationship between learning clinical procedural skills stage- 2 by giving the task of making clinical skills videos and reviewing or responding to lecturers as well as evaluating the effectiveness of stage-2 learning which is strong and the direction is positive. Based on the research results that there is a relationship between clinical learning stages-1 and 2, namely learning using videos and lecturers' explanations, giving the task of making clinical skills videos and reviews or responses from lecturers as well as learning effectiveness is very strong and has a positive direction.

\section{REFERENCES}

[1]. Abel, T., \& McQueen, D. (2020). The COVID-19 pandemic calls for spatial distancing and social closeness: not for social distancing! International 
Journal of Public Health. https://doi.org/10.1007/s00038-020-01366-7

[2] Darmalaksana, W., Hambali, R. Y. A., Masrur, A., \& Muhlas. (2020). Analisis Pembelajaran Online Masa WFH Pandemic Covid-19 sebagai Tantangan Pemimpin Digital Abad 21. Karya Tulis Ilmiah (KTI) Masa Work From Home (WFH) Covid-19 UIN Sunan Gunung Djati Bandung Tahun 2020,1(1),1-12

[3] Andrian, R., \& Fauzi, A. (2020). Security Scanner For Web Applications CaseStudy: Learning Management System. Jurnal Online Informatika, 4(2), 63.https://doi.org/10.15575/join.v4i2.394

[4] Meiza, A., Hanifah, F. S., Natanael, Y., \& Nurdin, F. S. (2020). Analisis Regresi Ordinal untuk melihat Pengaruh Media Pembelajaran Daring terhadap Antusiasme Mahasiswa Era Pandemi Covid. In Digital Library UIN Sunan Gunung Jati. Retrieved from http://digilib.uinsgd.ac.id/30730/1/artikel KTI final asti dkk.pdf

[5] Tosida, E. T., Huda, A. S. M., Wahyudi, I., Andria, F., Djatna, T., Hermadi, I., Putra, M. R. A. (2020).

Optimization of topic mining and sentiment analysis for telematics

workforcedevelopmentstrategies.International Journal of Advanced Science and Technology, 29(7 Special Issue), 3790-3801.

https://www.scopus.com/inward/record.uri?eid=2s2.0.8 5085624913\&partnerID=40\&md5=7ee0b483a35108e61 32a500272ed9ab7

[6] Dharma. (2011). Metodologi Penelitian Keperawatan. Jakarta: CV. Trans Info Media.

[7] Try Ayu Patmawati, Ariyanti Saleh, Syahrul Syahrul. (2018). Efektifitas Metode Pembelajaran Klinik Terhadap Kemampuan Berpikir Kritis dan Kepercayaan Diri Mahasiswa Keperawatan : A Literature Review. Jurnal Keperawatan Muhammadiyah 3 (2) 2018.

[8] Lisiswanti, Rika \& Saputra, Oktadoni. (2015). Refleksi dari Pembelajaran Laboratorium Keterampilan Klinik. Bagian Pendidikan Kedokteran, Fakultas Kedokteran, Universitas Lampung.

[9] Nyimas Natasha Ayu Shafira, Charles A.S, Citra Maharani. (2018). The influence of video learning media addition on neuromotoric physical examination clinial skill of medical student faculty of medicine and health sciences Jambi University. JMJ, Volume 6, Nomor 2, November 2018, hal 165-170

[10] Nindya Aryanty, Anggelia Puspasari, Anati Purwakanthi. (2014). Perbandingan Efektivitas Pembelajaran Clinical Skill Lab (CSL) dengan Menggunakan Video Ajar Keterampilan Klinik
Neurologi terhadap Demonstrasi oleh Instruktur. JMJ, Volume 2, Nomor 2, November 2014, Hal : 189 - 196. 